\title{
Guideline for Authors
}

Please notice the following requirements:

\section{Size}

Articles, reports and other contributions to the journal should be submitted in English or German. Articles should not exceed 25 pages with 60 stops per line and 35 lines, including graphics and bibliography; reply or discussion papers, conference reports, book reviews etc. should have not more than 5 pages.

Send the article in 2 copies to the editor. Add a disc with the article, if possible in Microsoft Word for Windows format.

\section{Abstract}

The articles should include an abstract of 100 or fewer words. As far as possible the abstract should be written in english and german language.

\section{Paragraphs, Type size etc.}

Please use only "Times New Roman”as type.

Use simple spacing.

Do not use automatic or manual word division.

Paragraphs should be connected without blank spacing.

Abbreviations, if not used internationally, should be avoided.

\section{Titles}

Main titles should be printed in bold types, secondary titles in bold types and italics, tertiary only in italics.

\section{Quotations in the Text}

mentioning of author: Name (Year)

quotation of authors: $\quad$ (Name/ Name Year:Page)

quotation of different sources (Name Year; Name Year:Page)

more than 2 authors: $\quad$ Name of 1st author et al. (Year:Page)

\section{Footnotes}

Footnotes should be kept shortly. They should not be used for citing references

\section{Tables and figures}

Tables as well as Firures should be numbered consecutivly (arabic numerals) and contain a short title.

Table [Number]: [Titel] resp. Figure [Number]: [Titel]

In order to refer to tables or figures within the text only the number should mentioned

As it can be seen in Table [Number] resp. (see Fig.[number]) 
The size of tables should not, the size of figures must not exceed one page (A4: (210 X $297 \mathrm{~mm}])$. The spacing and lettering should allow for subsequent reduction to the size of JEEMS page (A5)

Tables and Figures which are not yet embedded in the text, should be sent in a separate file with indication of the program used.

\section{References}

Vedin, B.-A. (ed.) (1994): Management of Change and Innovation, Aldershot et al.

Madhavan, R./ Fogel, D.S. (1992): In Support of Reform: Western Business Education in Central and Eastern Europe, in: Review of Business, No. 4, pp 4-9.

\section{Short biography}

For a short biography of the author, please state the following items:

Surname, Christian name, year of birth, academic titles, institution, department, main research topics.

\section{Assessment procedure}

All papers will be screened by a member of the editorial board and blindly reviewed by East resp. West European members of the corresponding board. For further communication send the full address and if possible the e-mail address. 


\section{Richtlinien für Autoren}

Bitte beachten Sie folgende Anforderungen:

\section{Art und Umfang}

Artikel, Berichte und andere Beiträge für JEEMS sollten in deutscher oder englischer Sprache verfaßt sein. Die Artikel sollten einen Umfang von max. 25 Seiten mit 60 Anschlägen und 35 Zeilen pro Seite, einschließlich Abstract, Grafiken und Literatur, haben; alle anderen Beiträge sollten einen max. Umfang von 5 Seiten haben.

Der Artikel sollte in 2 Exemplaren an den Herausgeber geschickt werden. Beigefügt werden sollte eine Diskette mit dem Artikel, wenn möglich im Format Microsoft Word für Windows.

\section{Abstract}

Artikel sollten ein Abstract von höchstens 100 Worten, wenn möglich in deutscher und englischer Sprache enthalten

\section{Schriftart, Absätze etc.}

Der Artikel ist vollständig in der Schriftart “Times New Roman” zu verfassen Der Text sollte im einfachen Zeilenabstand geschrieben werden.

Silbentrennungen sind nur mittels bedingtem Trennstrich vorzunehmen.

Absätze sollten nicht durch Lerzeilen getrennt werden.

Abkürzungen, soweit sie nicht international gebrächlich sind, sollten vermieden werden.

\section{Überschriften}

Hauptüberschriften sollten fett, Überschriften 2. Ordnung fett/kursiv und Überschriften 3. Ordnung kursiv geschrieben sein.

\section{Zitate im Text}

Erwähnung des Autors:

Zitieren von Autoren:

Hinweise auf verschiedene Autoren:

mehr als 2 Autoren:
Name (Jahr)

(Name/ Name Jahr:Seite)

(Name Jahr; Name Jahr:Seite)

Name des ersten Autors et al.

\section{Fußnoten}

Fußnoten sollten kurz gehalten werden. Sie sind nicht für Literaturangaben zu nutzen. Fußnoten sollten am unteren Rand der Seite stehen, auf der sie gebraucht werden. 


\section{Tabellen und Grafiken}

Tabellen und Graphiken sollten jeweils eigene durchgehende Nummerierungen (arabisch) haben und mit einem Kurztitel versehen sein.

Tabelle [Nummer]: [Tilel] bzw. Abbildung [Nummer]: [Titel]

Verweise auf Tabellen oder Graphiken im Text sind nur mit der Nummer zu versehen.

Wie Tabelle [Nummer] zeigt bzw (siehe Abb.[Nummer])

Tabellen sollten, Graphiken dürfen nicht größer als eine Seite sein. Es ist darauf zu achten, daß sie bei Reduzierung auf die Standardgröße von JEEMS (A5) lesbar bleiben

Tabellen/ Grafiken die nicht im Text eingebettet wurden, sollten in einer separaten Datei gesendet werden, mit dem Namen des Programms in dem diese erstellt wurden.

\section{Literaturverzeichnis}

Meissner, B./ Loeber, D./ Levits, E. (Hrsg.) (1992): Die Wirtschaft der baltischen Staaten im Umbruch, Köln.

Stratemann, I. (1994): Personalauswahl und -entwicklung in den neuen Bundesländern, in: Zeitschrift Arbeits- und Organisationspsychologie, Nr. 1, S. 41-44.

\section{Kurzbiographie}

Für einen Kurzbiographie der Autoren sollten folgende Informationen beigefügt werden:

Name, Vorname, Geburtsjahr, Titel, Institution, Abteilung, Forschungs/Arbeitsschwerpunkte.

\section{Bewertung}

Alle Beiträge werden von einem Mitglied des Herausgeberrates überprüft und von einem ost- resp. westeuropäischen Mitglied des Mitarbeiterkreises rezensiert. Zur Erleichterung der weiteren Kommunikation ist die komplette Adresse des Autors - wenn möglich mit E-Mail Adresse - erforderlich. 